\title{
STRATEGIC COOPERATION BETWEEN JAPAN AND KAZAKHSTAN: A NEW STAGE IN THE STRENGTHENING OF THE STRATEGIC PARTNERSHIP
}

\author{
Lyailya Nurgaliyeva*
}

\begin{abstract}
This paper focuses on an emerging form of a strategic relationship between Japan and Kazakhstan, a so-called "strategic cooperation" based on energy development cooperation. In contrast to the views taken by some experts studying the specifics of the Japan-Kazakhstan relations, the author argues that Japan has a strategy in its foreign relations with Kazakhstanthe "strategic cooperation". Over twenty years, the two countries continuously explored and tried to find mutually beneficial entry points in their relations. There were several contributing factors that spurred the inception and growth of the "strategic cooperation". First, Kazakhstan's steady economic growth changed its status from a recipient of ODA from Japan to an equal partner. Second, Kazakhstan needed high technologies to change its role of being simply an exporter of raw materials to producer of processed raw materials, while Japan has been exploring new sources of energy to decrease its dependence on Middle East.
\end{abstract}

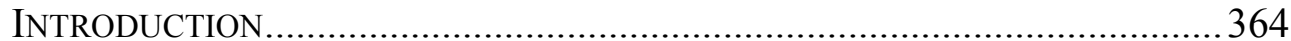

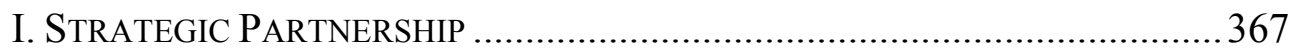

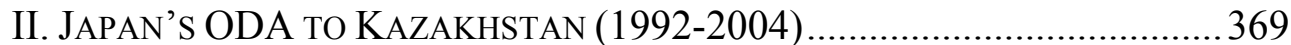

III. STARTING POINT OF THE STRATEGIC PARTNERSHIP (1999 )...................372 IV. Strategic CoOperation as a NeW Stage In the Strengthening OF

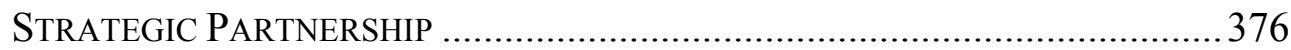

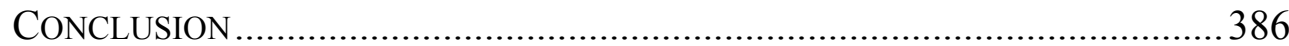

\section{INTRODUCTION}

After the collapse of the Soviet Union in 1991, Japan and Kazakhstan established a diplomatic relationship. However, for an extended period of time until 2006, there was no major progress in the economic relationships between the two countries. There was almost no trade between Kazakhstan and Japan in the 1990s. In 2002, both countries tried to spur trade between them through a variety of political and economic initiatives, with the focus on the development of oil and gas production in the Caspian Sea. Yet, this also did not result in any large-scale trade between the two countries. The

\footnotetext{
${ }^{*} \mathrm{PhD}$ Candidate, Faculty of Social and Cultural Studies, Kyushu University, Japan. Research fields: International Cooperation, Energy Security and Foreign Policy of Kazakhstan.
} 
author calls that period (the period from the establishment of the diplomatic relationship between the countries and up to 2006) in the relationships of Kazakhstan and Japan a period of "strategic partnership". In 2006, however, a new stage in the bilateral relationships between Kazakhstan and Japan was reached. Instead of scattering their attention over a wide variety of initiatives, the countries started focusing their cooperation on the development of uranium and rare metals. This initiative, in its turn, resulted in a significant rise in trade between Kazakhstan and Japan and the change in the nature of the relationship between the two countries from a donorrecipient relationship to a partnership of equals. The author calls this period from 2006 through today-the period of "strategic cooperation".

The collapse of the Soviet Union ushered in the emergence of the newly independent states in the centre of Eurasia, including a number of states in Central Asia, with Kazakhstan being the largest state in Central Asia (ninth in the world). In light of the Central Asian's geopolitical importance and in order to maintain regional stability, starting from 1992 various players from the developed world thought it was important to provide ODA to establish diplomatic relations with, the former Soviet Union countries in the Central Asian region. Japan became one of the top ODA donors to the Central Asian countries.

By launching the Central Asia Plus Japan Initiative in 2004 and the New Energy Program of 2006 in lieu of the ODA, Japan focused on developing a more resource-oriented approach towards Central Asia with a major focus on Kazakhstan. Looking at these developments, therefore, it is timely to examine the newly emerging form of the Japan-Kazakhstan bilateral relationship, which the author calls "strategic cooperation". The author will elaborate on this term in Section One below.

The views in the literature on the subject of the Japan-Kazakhstan cooperation can be divided into the following two opposite groups:(1) views of those experts who argue that Japan does not have any developed strategy toward Central Asia, including Kazakhstan, and (2) views of those experts who insist that there is a strategy on the part of Japan in its policy towards Central Asia.

The first point of view is expressed by Uyama Tomohiko, ${ }^{1}$ who says that Japan does not have national interests in Central Asia or the need to maintain security there. In his opinion, the concept of a "strategy" presupposes the existence of prevailing interests. Accordingly, he argues

\footnotetext{
${ }^{1}$ Tomohiko Uyama, Japanese Policies in Relation to Kazakhstan: Is There a Strategy? in THINKING Strategically: The Major Powers, KaZaKhstan, And the Central Asian Nexus 165-186 (Robert Legvold ed., Cambridge/MIT Press 2003).
} 
that because of the transportation difficulties, Japan is not interested in the energy resources of Kazakhstan, and, consequently, Japan does not have any strategy towards Kazakhstan.

The authors who belong to the second group point to political contacts and economic relationships in arguing that Japan has a strategy toward Central Asia and Kazakhstan. A) David Walton, ${ }^{2}$ for instance, wrote that in the post-Cold War era a new model for Japan emerged-Japan as an "adaptive state", which means that Japan is seeking a more assertive role on the international arena while remaining within the US-led hegemonic system. David Walton examines the adaptive state model in Japan's strategy toward Central Asia. He explains that the early policy, which was driven by a few key policy-makers sympathetic towards countries in Central Asia, was to establish a close rapport with the elite policy-makers in Central Asia. B) Murat Laumulin's ${ }^{3}$ argument is that in 1993 trade relations between Japan and Kazakhstan intensified. As a result of contacts in the economic sphere, on August 19, 1993, the Japanese-Kazakhstan Committee on Economic Cooperation was created. Another author, Christopher Len, ${ }^{4}$ is also of the opinion that the economic strategy was the primary focus on the Japan's policy toward Central Asia, including Kazakhstan. In 1993, the Japan National Oil Corporation (JNOC) announced the carrying out of a fullyfledged commercial production of oil and gas. C) Timur Dadabaev ${ }^{5}$ in his work noted that Japan's policy toward Central Asia, including Kazakhstan, culminated in the first visit by the Japanese Prime Minister, Koizumi Junichiro, to the Central Asian republics of Kazakhstan and Uzbekistan in August of 2006 as part of Japan's efforts to shape its foreign policy towards the region.

However, these authors do not examine what the underlying reasons were for the transition into a greater cooperation between Japan and Kazakhstan. The purpose of this study is to examine the reason sunder lying the decrease in the levels of ODA provided by Japan to Kazakhstan and the

\footnotetext{
${ }^{2}$ David Walton, Japan and Central Asia in The New Central AsIA 261-277 (Emilian Kavalski ed., World Scientific Publishing Co. Pte. Ltd. 2010).

${ }^{3}$ Murat Laumulin, Strategiya Yaponii v Evrazii, v TSEnTRAL'NAYA AzIYA V ZARUBEZHNOI PolitologiI I Mirovoi GEOPOLITIKe (The strategy of Japan in Eurasia, in CENTRAL ASIA IN WORLD Politics AND GeOPOLITICS) 184-192 (Almaty 2009).

${ }^{4}$ Christopher Len, Understanding Japan's Central Asian Engagement, in JAPAN's SILK ROAD DiPlOMACY: PAVING THE ROAD AHEAD 31- 46 (Christopher Len, Uyama Tomohiko, Hirose Tetsuya eds., Central Asia-Caucasus Institute \& Silk Road Studies Program 2008), pp..

${ }^{5}$ Timur Dadabaev, Models of Cooperation in Central Asia and Japan's Central Asian Engagements: Factors, Determinants and Trends, in JAPAN's Silk RoAd DiPlomacy: PAVIng THE ROAD AHEAD 121-140 (Christopher Len, Uyama Tomohiko, Hirose Tetsuya eds., Central Asia-Caucasus Institute \& Silk Road Studies Program 2008).
} 
transition to "strategic cooperation" with Kazakhstan. In this regard, the author examines the following two questions. First, what were the major factors that contributed to the change in the Japanese policy toward Kazakhstan from being the main ODA donor to Kazakhstan to moving to "strategic cooperation"? Second, what interests is Japan pursuing in its efforts to strengthen its relations with Kazakhstan, and what does cooperation with Japan mean to Kazakhstan? In exploring answers to these questions, this paper examines the diplomatic relations between Japan and Kazakhstan and analyzes the objectives and results of their bilateral relationship.

This article consists of four sections. Section One focuses on the discussion of "strategic partnership" and explores, among other things, the meaning of "strategic partnership", its role as the soft balancing measure by Kazakhstan in its relations with China and Russia, and, most importantly, the differences between "strategic partnership" and "strategic cooperation". Section Two provides an overview of Japan's ODA in Kazakhstan. Section Three provides a historical background of the Japan-Kazakhstan strategic partnership. Section Four examines the evolution of the Japan-Kazakhstan relationship from "strategic partnership" to "strategic cooperation".

\section{STRATEGIC PARTNERSHIP}

"Strategic partnership" is an important concept used in the international relations to describe a certain type of relationship between the international players. Initially, the word "strategy" had a strong military aspect and was used as the art of distributing and applying military means to fulfill the ends of policy. However, the economic globalization spurred the formation of economic partnerships between or among different enterprises to implement a firm's long-term business plans. Strategic partnership was originally used by the Japanese companies, which quickly learned that in the environment of growing globalization, it is difficult to survive alone. According to Vidya Nadkarni, ${ }^{6}$ in the post-Cold War period, strategic partnerships were used as an instrument of foreign policy. For instance, after the collapse of the Soviet Union, the United States exercised this instrument to pursue its interests in the Ukraine and Romania, both of which were not members of the NATO. Moreover, Vidya Nadkarni writes:

The following are the main characteristics of the strategic partnerships: (1) they are determined in multiple written declarations, statements, agreements, and memorandums of understandings, (2) they create formal institutional links at

\footnotetext{
${ }^{6}$ Vidya NADKARNi, Strategic PARTNerships in Asia 48-49 (London, Routledge 2010).
} 
various governmental (official) and non-governmental (people-to-people) levels, (3) they arrange a mechanism for summit meetings among top leaders, with more frequent meetings at the sub-ministerial and bureaucratic levels, (4) they work to develop ties between particular military authorities through joint military exercises and confidence building measures, (5) they try to establish stronger economic relationships, and (6) they promote greater awareness of each other's culture through youth exchanges and cultural fairs. ${ }^{7}$

The Japan-Kazakhstan relationship could be argued to present a strategic partnership as all five of the characteristics intrinsic to a strategic partnership are present in the Japan-Kazakhstan relationship. These characteristics developed in the Japan-Kazakhstan relationship in the following order: (3) first political relations were established between Kazakhstan and Japan; (5) subsequent to the establishment of the political relations, the countries commenced the development of economic relations with Japan commencing the ODA program; (6) promotion of personnel exchange followed the development of economic relations; (2) the Central Asia Plus Japan Dialogue initiative announced in 2004, and (1) the memorandums signed by the Japanese and Kazakhstan governments.

What does the strategic partnership with Japan mean to Kazakhstan? Pinar Ipek ${ }^{8}$, Avinoam Idan and Brenda Shaffer ${ }^{9}$ argue that Kazakhstan has been following a multi-vector foreign policy due to its oil-led development and it being a landlocked country, which significantly complicates the oil exports from the country. Kazakhstan's geopolitical imperatives force the country to maintain good relations with its neighbors, Russia and China. At the same time, Kazakhstan has concerns regarding Russia and/or China establishing hegemony in the region. Therefore, Kazakhstan has made a strategic decision to counterbalance the growing influence of China and Russia by means of diplomatic strategies, including establishing a strategic partnership with Japan. In other words, Kazakhstan has been using soft balancing. It was essential for Kazakhstan to use soft balancing to constrain Russia's and China's power and to maintain the country's security. Kazakhstan sees Japan as a balancing power in Kazakhstan's relationships with China and Russia and a trustworthy consumer of the country's energy resources.

What needs to be differentiated is the difference between Strategic Partnership and Strategic Cooperation. Cooperation cannot be one-sided.

\footnotetext{
${ }^{7}$ Ibid.

${ }^{8}$ Pinar Ipek, The Role of Oil and Gas in Kazakhstan's Foreign Policy: Looking East or West? 59 (7) EUROPE-AsIA STUDIES 1179-1199 (2007).

${ }^{9}$ Avinoam Idan and Brenda Shaffer, The Foreign Policies of Post-Soviet Landlocked States, 27 (3) POST-SOVIET AFFAIRS 241-268 (2011).
} 
Cooperation means the action of working or acting together for a common purpose or benefit. The author views the cooperation between Kazakhstan and Japan as strategic because of the strategic interests involved in the process. Specifically, Japan is interested in the Kazakhstani natural resources, such as uranium and rare metals, while Kazakhstan is interested in the new technologies that Japan may offer in connection with the processing of the extracted natural resources so that Kazakhstan may transit from being an exporter of raw materials to becoming a producer of processed natural resources. At this point, Kazakhstan and Japan have found the mutually beneficial way to meet their interests and accomplish their goals.

In the opinion of the author, strategic cooperation is a next stage in the evolution of a strategic partnership, which implies a stronger and deeper partnership, but which is characterized by a narrower and more specific focus on a particular area of cooperation, such as, for example in the case of the Kazakhstan-Japan relationship, nuclear energy development and cooperation in the field of rare metals. As opposed to strategic cooperation, strategic partnership implies a more comprehensive approach, including economic, political, socio-cultural and other initiatives.

For purposes of examining the strategic cooperation between Kazakhstan and Japan, it is important to first look at the historical factors that set the ground for the transition of the Kazakhstan-Japan relationship to the new stage of strategic partnership - strategic cooperation. This is what the author does in the next sections.

\section{JAPAN’s ODA TO KAZAKHSTAN (1992-2004)}

From the early 1990 s to the mid-2000s, Japan's primary way of interacting with the countries of Central Asia was through its ODA grants, with the goals of that assistance being primarily political, rather than economic, in nature. Then, in 2002, assistance to Kazakhstan through ODA shifted from having political motives to being driven by economic considerations by virtue of the oil interests in the Kazakhstan's share of the Caspian Sea oil shelf.

After the collapse of the Soviet Union, Japan started opening embassies in the new Central Asian countries, and the heads of these countries were invited to visit Japan. For instance, the embassy of Japan in Kazakhstan was opened on January 20, $1993^{10}$ and the president of Kazakhstan, Nursultan

${ }^{10}$ KAZAKHSTANSKAYA PRAVDA 1 (January 21, 1993). 
Nazarbaev, visited Japan in April 1994. ${ }^{11}$

Starting from 1991, Japan has been offering various forms of assistance to the countries of Central Asia, and upon Japan's initiative, the Development Assistance Committee (DAC) of the Organization for Economic Cooperation and Development (OECD) included the Central Asian countries on the list of the ODA recipients. ${ }^{12}$ Japan's ODA to Kazakhstan in 2000 amounted to $\$ 83.3$ million. ${ }^{13}$ However, subsequently this amount decreased. In 2001, the ODA to Kazakhstan was \$43.9 million. While the 2003 and 2004 ODA from Japan to Kazakhstan exceeded \$130 million, in 2006, it drastically dropped to $\$ 24.9$ million. ${ }^{14}$ (See Table 1). The reasons for such increase in ODA funds are discussed in Section 3.

Table 1 Japan's ODA Disbursements to Kazakhstan

\begin{tabular}{lllll}
\hline Year & Loan Aid & Grant Aid & Technical Cooperation & Total \\
\hline 1999 & 47.64 & 8.66 & 11.15 & 67.45 \\
2000 & 63.79 & 9 & 10.54 & 83.33 \\
2001 & 24.57 & 5.8 & 13.55 & 43.93 \\
2002 & 20.11 & 0.92 & 9.1 & 30.13 \\
2003 & 120.76 & 4.89 & 10.62 & 136.27 \\
2004 & 116.32 & 5.58 & 8.86 & 130.76 \\
2005 & 59.97 & 1.09 & 5.1 & 66.17 \\
2006 & 19.4 & 0.94 & 4.53 & 24.87 \\
Total & 581.66 & 45.24 & 110.12 & 737.03 \\
\hline
\end{tabular}

Initial source: OECD/DAC from the website of the Ministry of Foreign Affairs of Japan ${ }^{15}$.

Japan also extended to Kazakhstan a number of loans to modernize its railroad construction (including the station "Druzhba"16 on the border with China), which exceeded 7,000 billion yen, ${ }^{17}$ constructed a bridge over river Irtysh in Semipalatinsk, which plays a strategic role in the development of domestic infrastructure, ${ }^{18}$ reconstructed the Astana airport, ${ }^{19}$ and repaired

\footnotetext{
${ }^{11}$ KaZAKhStAnsKaya Pravda $1-2$ (April 9, 1994).

${ }^{12}$ Christopher Len, Japan's Central Asian Diplomacy: Motivations, Implications and Prospects for the Region, 3(3) THE CHINA AND EURASIA FORUM QUARTERLY 127-149 (2005).

${ }^{13}$ Ministry of Foreign Affairs of Japan, Japan's ODA Disbursements to Kazakhstan. Available at http://www.mofa.go.jp/policy/oda/data/03ap_ca01.html\#KAZAKHSTAN (last visited January 15, 2015).

${ }^{14}$ Ibid.

15 Ibid.

${ }^{16}$ Druzhba means friendship in Russian language.

${ }^{17}$ KAZAKHSTANSKAYA PRAVDA (November 30, 1995).

${ }^{18}$ KAZAKHSTANSKAYA PRAVDA (November 18, 2000).

${ }^{19}$ KaZAKHSTANSKAYA PRAVDA (May 22, 1999).
} 
the roads and highways in the western part of Kazakhstan. ${ }^{20}$ In addition, Japan granted equipment and tools to the Kazakhstani colleges and universities (especially towards the Japanese language training), theaters, and hospitals. ${ }^{21}$ Japan also invited Kazakhstani officials, entrepreneurs, and students for training in Japan. The Japanese government conducted research on the prerequisites of the economic development (like the development of mineral and water resources) $)^{22}$ and worked with international organizations in extending financial aid to Kazakhstan. ${ }^{23}$ To ease the social difficulties caused by the systemic transformation and environmental issues, Japan carried out a community medicine improvement plan as a technical cooperation project in Semipalatinsk. ${ }^{24}$

The officially declared primary goals of the Japan's ODA to the countries of Central Asia were: (1) training of skilled professionals and strengthening of the system necessary for democratization and transition to a market economy, (2) development of infrastructure, particularly in the fields of transportation and communication, (3) support of healthcare and education, and (4) environmental protection. ${ }^{25}$ But what were the real reasons for Japan to be such a generous donor to the Central Asian countries? To answer this question, the author will examine the economic and trade relations of the applicable players.

Initially, the economic interests of Japan in Central Asia did not serve as a main driving force in its policies due to the poor infrastructure and low consumption in the region. The risk-adverse Japanese companies were very careful in assessing any investment projects that were not supported by the framework of ODA. However, Kazakhstan needed investments to develop its industries. At that time, the oil companies and processing plants were in critical condition (due to the lack of financial support, many of such Kazakhstani businesses had to file for bankruptcy). ${ }^{26}$ This factor delayed the evolution of the Japan-Kazakhstan cooperation in the area of natural resources development.

The extension of the ODA to Central Asia appeared to bed one initially not for economic reasons but in pursuit of Japan's political interests of

\footnotetext{
${ }^{20}$ KaZAKHSTANSKAyA PRAVDA (April 4, 2000).

${ }^{21}$ KaZAKHSTANSKAYA PRAVDA (July 25, 1997).

${ }^{22}$ KAZAKHSTANSKAYA PRAVDA (March 15, 2006).

${ }^{23}$ Ministry of Foreign Affairs of Japan. Available at http://www.mofa.go.jp/policy/oda/data/pdfs/kazakhstan.pdf (last visited January 17, 2015).

${ }^{24}$ KazAKhStansKaya Pravda (September 4, 1999).

${ }^{25}$ Ministry of Foreign Affairs of Japan. Available at http://www.mofa.go.jp/mofaj/gaiko/oda/shiryo/kuni/09 databook/pdfs/03-02.pdf (in Japanese) (last visited January 17, 2015).

${ }^{26}$ KaZAKhSTANSKAYA PRAVDa (September 9, 1995).
} 
increasing its international prestige and taking what it considered its share of responsibility in maintaining international stability, especially in Asia. In light of the fact that a number of the Central Asian countries border with either or both of China and Russia, which was important in terms of maintaining security in Asia, ${ }^{27}$ Japan was extending the ODA grants to the Central Asian countries and proposed its "Central Asia plus Japan Dialogue" initiative as a way to monitor the situation in Central Asia and to maintain stability in the region. After the collapse of the Soviet Union, the Central Asian countries were economically weak and could easily fall under the influence of Russia and China. Therefore, Japan used ODA to curb the influence of those countries. This was especially true for Kazakhstan, which is the only Central Asian state sharing a long border with Russia, and the only Central Asian state whose government worked to reduce the risk of falling under the control of its big neighbors, Russia and China. Thus, the policies of Kazakhstan and Japan seemed to find a point of intersection.

The interests of the Japanese government in Central Asia in the post-Cold War period can be explained primarily by its desire to increase the prestige of Japan on the world arena and to strengthen its diplomatic relationships with the Asian countries. While the Japanese government may have looked forward to future economic benefits, the primary immediate motivations were political. Kazakhstan was more focused on immediate economic benefits. It hoped its relationship with Japan might produce significant dividends, considering the economic weight of Japan in the Asian-Pacific Rim.

\section{Starting Point OF THE StRATEgic PARTNERShip (1999 )}

On July 24, 1997, the prime minister of Japan, Hashimoto Ryutaro, in his speech to the Japan Association of Corporate Executives, presented a concept of the "Eurasian diplomacy". ${ }^{28}$ He stated that Japan would work to actively develop its relationships with China, Central Asia, and the Caucasus. These principles were somewhat abstract and sounded more like slogans.

To end the two-year pause and to activate the bilateral relationship, the president of Kazakhstan, Nursultan Nazarbayev paid a visit to Japan on December 5-8, 1999. As the result of this visit, Nazarbayev and the Prime Minister of Japan, Keizo Obuchi signed the "Joint Statement on Friendship,

\footnotetext{
${ }^{27}$ KAZAKHSTANSKAYA PRAVDA (January 26, 1993).

${ }^{28}$ Address by Prime Minister Ryutaro Hashimoto to the Japan Association of Corporate Executives (July 24, 1997). Available at http://www.kantei.go.jp/foreign/0731douyukai.html (last visited January 19, 2015).
} 
Partnership and Cooperation", thereby setting a formal framework for the strategic partnership and friendship based on the principles of mutual benefit, respect, and support for each country's sovereignty and territorial integrity. Both sides also emphasized the importance of mutual cooperation in the exploitation of oil and other resources in Kazakhstan, ${ }^{29}$ in particular with regard to attracting Japanese investments in the mining industry, including the production of molybdenum, tungsten, ilmenite, and uranium. The arrival of such companies as Marubeni and Mitsubishi to the market of Kazakhstan showed Japan's interest in the exploration and future development of Kazakhstan's energy resources.

In April 2002, a high-level economic delegation headed by Seiken Sugiura, the Senior Vice-Minister for Foreign Affairs of Japan, which included the Japanese scientists and business men from the oil and gas processing sector, visited Kazakhstan. ${ }^{30}$ Soon thereafter, on November 11 , 2002, Yuriko Koike, a member of the Japanese Diet and the new leader of the Conservative Party, visited Kazakhstan to meet with the Kazakhstani political parties and non-governmental organizations. ${ }^{31}$ Bilateral contact continued to expand with the official visit by the Kazakhstan Minister of Foreign Affairs, Kasymzhomart Tokaev, ${ }^{32}$ who visited Japan on December 3-7, 2002 in response to the invitation of the Minister of Foreign Affairs of Japan, Yoriko Kawaguchi. Through those economic and political meetings, the Japanese Government allocated 200 million dollars for oil exploration works in the Caspian Sea. ${ }^{33}$

On June 19, 2003, Nazarbayev met with the deputy of the House of Representatives of the Parliament of Japan, Yoshiro Mori in Astana and expressed the wish to sign a tax treaty between the countries to avoid double taxation. During that meeting, Mori noted: "Kazakhstan is seen as the main partner of Japan in the Central Asian region, and the Japanese government is committed to maintain a high level of cooperation with Kazakhstan". ${ }^{34}$ The

\footnotetext{
${ }^{29}$ Joint Statement on Friendship, Partnership and Cooperation between Japan and the Republic of Kazakhstan (December 6, 1999). Available at http://www.mofa.go.jp/region/europe/kazakhstan/pv9912/joint.html (last visited January 19, 2015).

${ }^{30}$ KAZAKHSTANSKAYA PRAVDA (June 12, 2002).

${ }^{31}$ KaZAKHSTANSKAYA PRAVDA (November 12, 2002).

${ }^{32}$ Besides Kawaguchi, Tokaev visited several other government and industrial leaders.

${ }^{33}$ Yapontsy hotyat kupit' nemnozhko Kaspiya (in Russian) (Dec. 4, 2002). Japanese Want to Purchase Some Caspian Sea Oil. Available at http://www.nomad.su/?a=4-200212040720 (last visited January 21, 2015.

${ }^{34}$ Prezident RK predlagaet zakluchit's Yaponiei soglashenie ob izbezhanii dvoinogo nalogooblozheniya (in Russian) (June 19, 2003). The President of Kazakhstan Offers to Conclude an Agreement with Japan on Avoidance of Double Taxation. Available at http://www.nomad.su/?a=3200306200022 (last visited January 21, 2015).
} 
meeting played a significant role in changing Japan's foreign policy towards Kazakhstan. The Ministry of Foreign Affairs of Japan put the new initiatives towards Kazakhstan. For instance, in 2004, the Minister of Foreign Affairs of Japan, Yuriko Kawaguchi announced Japan's "Central Asia plus Japan Dialogue" initiative. Its distinctive feature was to encourage the Central Asian regional integration and to enhance the capacities of these countries to deal with the regional problems by regional means. ${ }^{35}$ This foreign policy direction was further supported by the Minister of Foreign Affairs of Japan, Taro Aso, who in a June 2006 speech stressed a regional holistic approach to Central Asia, support for regionalism, and the promotion of democracy and a market economy in the region. ${ }^{36}$ Such attempts by Japan to assert a more active Central Asian diplomacy were seen by many as part of the Japanese efforts to limit Russian and Chinese power over the Central Asian countries. ${ }^{37}$

In the author's opinion, the driving force for these 2002-2006 initiatives was a desire for a strategic partnership based on economic ties between Japan and Kazakhstan. Why, in the 1999-2002 periods, after several years of passivity, did the Japanese foreign policy towards Central Asia become active? After entering the new millennium, Japan seemed to have reconsidered its 1990s foreign policy and started to expand its diplomatic relations with Kazakhstan towards a more intense economic strategy. In the late 1990s, new and vast deposits of critical natural resources, such as oil and rare minerals were discovered in Kazakhstan, which appealed to the energy-poor Japan. After the oil crisis of 1973, the Japanese who wished to reduce their dependency on the Middle Eastern oil were constantly looking for the new sources of energy supply. However, doubts regarding the regional stability in the Central Asian region, the poor infrastructure, the transportation issues, and the high investment risk seemed to have deterred the Japanese companies from making heavy investments in Kazakhstan. This, however, changed in 1999-2002, when the Japan and Kazakhstan began their strategic partnership.

It appears that the two main reasons why Japan decided to increase its involvement in Kazakhstan in 1999-2002 were (1) the role of Kazakhstan in maintaining regional security, and (2) the Japanese initiative to become a permanent member of the UN Security Council. In terms of regional

\footnotetext{
${ }^{35}$ KaZAKhStanskaya Pravda (August 27, 2004).

${ }^{36}$ Timur Dadabaev, Japan's Central Asian Diplomacy and its Implications, in CENTRAL AsIACAuCASUs Institute ANALYST (June 9, 2006). Available at http://old.cacianalyst.org/?q=node/4173 (last visited January 22, 2015.

${ }^{37}$ Ibid.
} 
security, Kazakhstan is the largest and one of the most stable and economically developed countries in Central Asia, which is adjacent to Afghanistan. The stability in Central Asia directly affects the process of counter-terrorism and regional stability in the Middle East. As to the second reason, Japan saw an historical opportunity to become a permanent member of the UN Security Council after the 2004 United Nations Reform and the 2005, the 60th anniversary of the United Nations. To improve its chances of becoming a permanent member of the UN Security Council, the Japanese government started working on the enhancement of its international political status. To this end, by increasing its contributions to the economic development of Central Asia Japan became the largest ODA donor country in 2004. The Central Asian countries, in turn, by supporting Japan's accession as a permanent member of the UN Security Council, could gain not only capital and technical support from Japan, but also political balance in the region. The President of Kazakhstan, Nursultan Nazarbaev, in the early days of independence declared that Kazakhstan's foreign policy would be built on a "multi-vector approach", including Asia, Europe, and United States. Japan's 2004 "Central Asia plus Japan Dialogue", resulted in the renaming of the "Newly Independent States Division" within the Ministry of Foreign Affairs of Japan into the "Central Asia and Caucasus Division" in 2005. ${ }^{38}$ Together with Minister of Foreign Affairs of Japan, Taro Aso's June 2006 speech, the rising importance of Central Asia to the Japanese Government became apparent. At that stage, Japan's policy towards Central Asia, including Kazakhstan, changed from being ODA-centered to a strategic partnership in combination with ODA. Through the dialogue, exchange visits, and other forms of cooperation Japan's presence in Central Asia started expanding.

Among other things, the levels of trade between the two countries also started increasing during that period. In the 9 months of 2002, the total trade between two countries amounted to $\$ 149.5$ million, which was $45.5 \%$ higher than the total for $2001 .{ }^{39}$ After the December 2002 visit by the Minister of Foreign Affairs of Kazakhstan, Tokaev, the Japanese Government extended $\$ 800$ million to Kazakhstan in the framework of an ODA grant for purposes of oil exploration in the Caspian Sea. In turn, Tokaev noted that the main goal of the Government of Kazakhstan was to reduce the country's dependence on exports of raw materials. He hoped the experience of introducing Kazakhstan to the Japanese businessmen would

\footnotetext{
${ }^{38}$ Ministry of Foreign Affairs of Japan. Available at http://www.mofa.go.jp/mofaj/annai/honsho/sosiki/oushu.html (last visited January 22, 2015).

${ }^{39}$ KAZAKHSTANSKAYA PRAVDA (November 14, 2002).
} 
lead to joint projects that could help achieve that goal for Kazakhstan. ${ }^{40}$

However, that growth in trade between Japan and Kazakhstan did not result in growth in investments from Japan. The Japanese businessmen were extremely wary of making highly risky investments in Kazakhstan. The risks in Kazakhstan, in their opinion, could arise as a result of potential compliance issues in Kazakhstan and poor infrastructure. ${ }^{41}$ Furthermore, Russian and Chinese enterprises had already made inroads into the Caspian Sea oil development at that time. The Japanese companies did not believe that the low rate of return was worth the risk. Therefore, the levels of foreign direct investment (FDI) from Japan to Kazakhstan did not rise. To change the situation, on July 13, 2005, the Prime Minister of Kazakhstan, Daniyal Akhmetov met with Keishiro Fukushima, the Parliamentary Secretary for Foreign Affairs of Japan to discuss the issues of further cooperation between the two countries in various sectors of economy and in the area of technical cooperation, attracting new Japanese investments in Kazakhstan, and joint Kazakhstani-Japanese projects. ${ }^{42}$ That visit was the setting stage for the pivotal event in the history of the Kazakhstan-Japan bilateral relations - the 2006 visit of the Prime Minister of Japan, Koizumi Junichiro to Kazakhstan, which marked the transition of the countries relationship to a new stage of strategic partnership - strategic cooperation.

\section{Strategic CoOperation as a New Stage IN THE StRENGTHENING OF STRATEGIC PARTNERSHIP}

In August of 2006, the Japan-Kazakhstan relationship fundamentally changed as a result of the visits by the Prime Minister of Japan, Koizumi Junichiro to Kazakhstan and Uzbekistan, the first visits of the Japanese prime minister to these two Central Asian countries. Many observers noted that Koizumi's visit was part of Japan's new initiative towards the region. The initiator of this new development in the bilateral relations of Kazakhstan and Japan, however, was the President of Kazakhstan, Nursultan Nazarbayev. Here quested the Ambassador of Japan to Kazakhstan, Toshio Tsunozaki to facilitate a visit by the new Prime Minister of Japan to Kazakhstan upon his appointment to the office.

\footnotetext{
${ }^{40}$ KaZAKhStanskaya Pravda (December 5, 2002).

${ }^{41}$ KaZAKHSTANSKAYA PRAVDA (April 2, 2003).

${ }^{42}$ Prem'er-Ministr RK i Spetsial'niy poslannik Pravitel'stva Yaponii obsudili voprosy dal'neishego vzaimodeystviya dvukh stran (in Russian). Prime Minister of Kazakhstan and Parliamentary Secretary for Foreign Affairs of Japan discussed further bilateral cooperation. Available at http://news.gazeta.kz/news/premer-ministr-rk-i-specposlannik-pravitelstva-yaponii-obsudili-voprosydalnejjshego-vzaimodejjstviya-dvukh-stran-newsID200610.html (last visited January 23, 2015).
} 
Tsunozaki notes about it as:

"When I met with the President of Kazakhstan, Nursultan Nazarbayev, he told me that he wants the Japanese companies to increase the amount of private investments, as they are still low. ... and he requested a visit by the Prime Minister of Japan to Kazakhstan. In the last two to three years, the amount of investments has increased, but mostly they are made by INPEX to the Kashagan oil field. The amount of bilateral trade is increasing in general, but while the imports from Japan are increasing, the exports to Japan, mostly mineral resources, are not increasing significantly, which causes an imbalance in the bilateral trade". 43

There is an interesting phenomenon called the "resource curse" by social scientists. Paradoxically, countries with the abundance of natural resources, such as oil and gas, often perform worse in terms of economic development and good governance than those countries that lack natural resources. Earnings from the oil and gas production, if viewed as a source of income, are highly volatile because of the fluctuation in rates and the value of oil while produced. ${ }^{4}$ To overcome this kind of resource curse, Kazakhstan created a plan called "Strategy of Industrial and Innovation Development for 2003-2015", which was announced by President Nazarbayev in 2002. This strategy is focused on achieving a stable development of the country by means of economic diversification and shifting from extraction to processing. The required resources and sources of financing are direct investments, the costs of which for the strategy implementation are estimated to be approximately $\$ 1.2$ billion per annum. ${ }^{45}$ Production of competitive and export-oriented products, works and services in processing industries and in the sphere of services is the major issue of the state's industrial-innovational policy. ${ }^{46}$ To implement this project, the Embassy of the Republic of Kazakhstan in Japan has actively worked to attract the Japanese business community through Japan External Trade Organization (JETRO). ${ }^{47}$

Muzaparova Leila, the Deputy Director of the Kazakhstan Institute for

\footnotetext{
${ }^{43}$ Toshio Tsunozaki, zen chyu Kazafusutan Nihonkoku tokumeizenken taishi, Shirarezaru Shinkyoudaisanyukoku: Kazafusutan wa konna kuni (in Japanese). Former Japan's Ambassador Extraordinary and Plenipotentiary to Kazakhstan, New Large Oil Producing Countries Which Are Not Known: Kazakhstan Is Such a Country, Analysis, SekiYu, 40 (3) Tennen Gasu Rebyu 62 (2006).

${ }^{44}$ Macartan Humphreys, JefFrey D. SaChs, and Joseph E. STiglitz, Escaping the Resource CURSE 1-10 (Columbia University Press 2007).

${ }^{45}$ Innovative Industrial Development Strategy of Kazakhstan for 2003-2015. Available at http://www.embkazjp.org/innovativeindustrialdevelopment.htm (last visited January 24, 2015).

${ }^{46} \mathrm{Ibid}$.

${ }^{47}$ Sanae Kurita, Kazafusutan no enerugi seisaku to houtoku ajia no taio (in Japanese). The Energy Policy of Kazakhstan and the Correspondence of Northeast Asia, 33(2) ENERUGI KEIZAI 42 (2007).
} 
Strategic Studies, explained the preference for the Japanese investments as follows:

Japanese investments bring the new technologies, which are more improved and more profitable than American or European. In addition to this, the Japanese have a great responsibility in business... There are a lot of interesting projects, in which the Japanese companies are the absolute leaders by virtue of their knowhow in innovative industrialization. Russia and China in this regard are far behind Japan. ${ }^{48}$

A similar point of view is expressed by an independent analyst, Dosym Satpaev, the Director of the Kazakhstan Risk Assessment Group, who noted:

What is the advantage of Japan? As I have said before, the Japanese businessmen are different from their Russian and Chinese counterparts in that they are willing to invest in the innovation sector-processing and etc. Here the Japanese businesses showed themselves as investors in the non-extractive sectors, like uranium processing in Kazakhstan. Kazakhstan is interested in Japan as an innovative investor - one of the leaders on the global level, which has had success in the innovation projects. In this regard, as Kazakhstan moves forward with its industrial innovation program, the role of Japan will increase. Japan's experience in the innovation sector could help Kazakhstan in the successful implementation of this program and increase its influence, because neither Russia nor China, nor even the U.S., would actively work here. They are quite satisfied with Kazakhstan as a raw materials appendage. However, we are not satisfied with this role, and we are now actively trying to attract investors from countries such as Malaysia, Korea and Japan, who will invest in the non-extractive sectors. It turns out that the prospects of the bilateral relations with Japan depend on the development of Kazakhstan's interests and also whether Kazakhstan will create a favorable environment for the Japanese business. ${ }^{49}$

To attract the Japanese investments and to strengthen the economic relations between the two countries, Kazakhstan has adopted the "Convention for the avoidance of double taxation and the prevention of fiscal evasion with respect to income taxes", which became effective as of January 1, 2010.

This convention adjusts the taxation rights between Kazakhstan and Japan to avoid international double taxation arising from the economic and human exchanges. The Convention clarifies the limits of the withholding tax rates levied on dividends, interest and royalties (copyrights, patents and others), to promote

\footnotetext{
${ }^{48}$ Muzaparova Leila, Author's Interview with a Deputy Director of Kazakhstan Institute for Strategic Studies (Almaty, Kazakhstan, August 16, 2010).

${ }^{49}$ Satpaev Dosym, Author's Interview with an Independent Analyst and the Director of the Kazakhstan Risks Assessment Group (Almaty, Kazakhstan, August 17, 2010).
} 
mutual investments. ${ }^{50}$

While there a sons behind Kazakhstan's desire to deepen its relationship with Japan are more or less obvious, the question arises as to what then was the driving force behind Japan's focus on strengthening its relationship with the Central Asian countries, including Kazakhstan? Tsunozaki addressed this question in his article "The significance of strengthening the Kazakhstan-Japan relationship" published in Genshiryoku Eye:

First, Japan has supported the development of the market economy and democracy consistently since the independence of the Central Asian countries because the whole Eurasian continent depends on the stability and prosperity of this region. Without this stability there is a risk of [it] becoming a hotbed of terrorism or extremism. Second, although Japan does not have military presence in the region like the U.S., Japan is trying to strengthen its presence in Central Asia, near the China-Russia "backyard" to have..."A card towards China and Russia", which is not pleasant for China and Russia. ${ }^{51}$

In addition to the foregoing reasons, Japan was focusing on Kazakhstan because of its uranium and because atomic energy is a major source of energy in Japan. In 2001, atomic power made up of the majority of Japan's domestic energy production (although only $20 \%$ of Japan's total primary energy supply came from the domestic energy production). ${ }^{52}$

As a result of Koizumi's visit to Kazakhstan in 2006, the memorandum on cooperation on peaceful exploitation of nuclear energy and uranium mining development was signed. ${ }^{53}$ On April 30, 2007, the Minister of Economy, Trade and Industry of Japan, Amari Akira visited Kazakhstan and signed a joint statement on strengthening the strategic partnership in the field of peaceful use of atomic energy. Moreover, during the Amari's meeting with Nazarbaev, they discussed the development of economic

\footnotetext{
${ }^{50}$ Ministry of Foreign Affairs of Japan, Signing of the Convention between Japan and the Republic of Kazakhstan for the Avoidance of Double Taxation and the Prevention of Fiscal Evasion with Respect to Taxes on Income (December 19, 2008). Available at http://www.mofa.go.jp/announce/announce/2008/12/1185605_1080.html (last visited January 25, 2015).

${ }^{51}$ Toshio Tsunozaki, Kokusai kaihatsu koutou kyoiku kiko senmu riji (zenchyu Kazafusutan taishi), Nihon to Kazafusutan no kankei kyouka no igi (in Japanese). Toshio Tsunozaki, Executive Director of the Foundation for Advanced Studies on International Development and former Ambassador of Japan to Kazakhstan, Significance of the Strengthening of Japan-Kazakhstan Relationship, 52 (11) GENSHIRYOKU EYE 31-32 (2006).

${ }^{52}$ Syouji Sakai, Dai san shyo. Sougou enerugi seisaku: kokunai enerugi seisan, NiHON No ENERUGI SeISAKU, KoKUBETSU Shyousai SHINSA [Kokusai enerugi kikan (IEA), (2003) (in Japanese)]. Chapter 3, Comprehensive Energy Policy: Domestic Energy Production, Country-by-country Review of International Energy Agency (IEA) 25 (OECD/IEA, February 8, 2005).

${ }^{53}$ PANORAMa (August 25, 2006).
} 
collaboration, including cooperation in the fields of industrial technologies and atomic energy. Such cooperation was supposed to extend to the following areas: export of natural uranium, nuclear fuel production, technology exchange in the area of reactor building, and personnel trainings. ${ }^{54}$ Those visits paved the way not only for the countries cooperation on uranium mining, but also for the supply of the strategically important rare earth metals. Such diversification was key to achieving a wider "strategic partnership".

From 2003 to April 2006, China, the dominant player and the leader in the export of rare earth metals, began to restrict international sales of those metals. China then gradually established a quota system on its exports of rare earth metals, increased its export tariffs on such metals, stopped granting mining licenses, reduced the number of the Chinese companies allowed to export the rare earth metals, and took other measures in that direction. All this led to a critical shortage of the rare earth metals in the market. Japan, which is dependent on imports of natural resources for its high-tech exports, sharply felt the rare metals supply deficit problem. Japan had to look for another supply source outside of China. On June 20, 2008, the Prime Minister of Japan, Fukuda Yasuo and the President of Kazakhstan, Nursultan Nazarbaev signed a joint statement on cooperation, including in the nuclear energy field. ${ }^{55}$ During his visit, Nazarbaev noted that Kazakhstan would allocate $40 \%$ of its rare earth metal exports to Japan. Moreover, following his visit, in October 2009, Nazarbaev caused the creation of a joint venture between Kazatomprom, the national nuclear energy company of Kazakhstan, and Sumitomo Corporation of Japan ${ }^{56}$ called Summit Atom Rare Earth Company (SARECO), in which Kazatomprom owns $51 \%$ of shares and Sumitomo Corporation-49\%. SARECO is engaged in the export and sales of finished products. In addition, an agreement was signed for the creation of another joint venture, but with Toshiba Corporation for research, development, production, manufacture, and marketing of the rare metal and rare earth products. In two years, the joint venture with Toshiba is expected to develop a feasibility study on the extraction and deep processing of the rare earth metals and the expected cost-effectiveness and feasibility of developing new high-tech and knowledge-intensive industries on rare-earth metals in Kazakhstan.

In addition, Kazatomprom has three plants (uranium, tantalum, and beryllium), specializing in the production of materials not only for nuclear,

\footnotetext{
${ }^{54}$ GENSHIRYOKU NENKAN 424 (2007).

${ }^{55}$ Genshiryoku NenKan 428 (2008).

${ }^{56}$ Ibid.
} 
but also for aerospace and electrical industry. ${ }^{57}$ On March 12, 2009, Nazarbaev directed Talgat Musabaev, the Chairman of the National Space Agency of Kazakhstan, to develop a full-fledged space industry as part of the government program on the development of the national space activities for $2010-2014 .{ }^{58}$ One of the effective ways to establish the foundation for the development of high-tech industries is the development of space activities through the introduction of space technologies into the industrial production. Japan is one of the key players in such space activities and could help Kazakhstan in implementation of its government program. ${ }^{59}$ Therefore, on January 27, 2010, Japan and Kazakhstan agreed to cooperate in the field of space research and implementation of space technology for the benefit of both countries. ${ }^{60}$

Before the Koizumi visit in 2006, the Japan's Ministry of Trade and Industry established a new National Energy Strategy, which planned for the simultaneous achievement of the " 3 Es"-energy security, economic growth and environmental protection. A journalist of Asia Times, Hisane Masaki explained the purpose of this energy strategy as follows:

The purpose of this Energy Strategy was the reduction in the oil-dependency rate to $40 \%$ or less by 2030 from $50 \%$, promotion of nuclear energy, and securing of energy resources abroad through the fostering of more powerful energy companies. Moreover, the Japanese Government unveiled a plan to construct a new 1 trillion yen (approximately $\$ 8.7$ billion) fast-breeder reactor to extract plutonium at a spent-nuclear-fuel reprocessing facility. These Japanese moves toward greater energy security come amid the stubbornly high oil prices, the global competition for oil reserves is intensifying. This rush for oil reserves is being driven by China and India, which both desperately need stable oil and

\footnotetext{
${ }^{57}$ Evraziiskii Bank Razvitiya, Sotrudnichestvo Rossii i Kazakhstana v atomno-energeticheskom komplekse (in Russian). Eurasian Bank of Development, Cooperation between Russia and Kazakhstan in the Atomic Energy Industry 18-22 (Almaty 2011). Available at

http://www.eabr.org/general/upload/docs/publication/analyticalreports/full_version_11_rus.pdf (last visited January 27, 2015).

${ }^{58}$ Musabev proinformiroval Nazarbayeva o realizatsii proektov v kosmicheskoi otrasli (in Russian). Musabaev Informed Nazarbayev about the Realization of Projects in Space Industry (March 12, 2009). Available at http://profit.kz/news/4651-T-Musabaev-proinformiroval-N-Nazarbaeva-orealizacii-proektov-v-kosmicheskoj-otrasli/ (last visited January 27, 2015).

${ }^{59}$ Kazakhstan Respublikasi Ukimetinin 2010 zhylgy 29 kazandagy №1125 kaulisi. Kazakhstan Respublikasinda garysh kizmetin damitu zhonindegi 2010-2014 zhyldarga arnalgan bagdarlamani bekitu turali (in Kazakh). Resolution of the Government of the Republic of Kazakhstan from October 29, 2010 № 1125. Approval of the Program for the Development of Space Activities in the Republic of Kazakhstan for 2010-2014. Available at http://adilet.zan.kz/kaz/docs/P1000001125 (last visited January 27, 2015.

${ }^{60}$ Nurgaliyeva Sara, Kazkosmos i Yaponskoe Agenstvo Aerokosmicheskih issledovanii podpisali soglashenie o sotrudnichestve v mirnih tselyah (in Russian). Kazkosmos and the Japan Aerospace Exploration Agency Signed an Agreement on Cooperation in the Peaceful Uses, KAZINFORM (January 27, 2010). Available at http://www.inform.kz/rus/article/2231790 (last visited January 27, 2015).
} 
energy supplies to power their booming economies. New sources of energy have turned into new sources of potential tension and conflict, as being exemplified in East Asia by the gas dispute between Tokyo and Beijing in disputed waters in the East China Sea. ${ }^{61}$

Moreover, the Prime Minister Koizumi took in account several factors, including: Kazakhstan's position as the world's third largest producer of uranium, Japan's desire to increase the share of nuclear energy to $30 \%-40 \%$ of its total energy consumption, and the rising global prices on uranium, which for 10 months in 2006 grew by $64 \%$ and were $\$ 60$ per pound. Those factors played a key role in the evolution of the Kazakhstan-Japan relationship from a wide but shallow strategic partnership to a deeper and more focused minerals-based cooperation. Among indicators of such evolution were the 24 uranium-based agreements signed by the Kazakhstan and Japanese companies in 2007, the highest number of agreements ever signed between the representatives of these countries. This does not only symbolize the national interest of Japan to secure a stable supply of energy, but also reflects on the desire of the Japanese companies to have governmental commitments in securing access to energy resources. ${ }^{62}$

Kazakhstan's relations with Japan from 2006 to 2012 were based on the concept of "new partnership", which is being provided through greater economic cooperation. The trade turnover between the two countries for the period 2008-2012 amounted to $\$ 7$ billion, while imports were equal to $\$ 3.4$ billion and exports $\$ 3.5$ billion. Moreover, Japan's direct investments for the past 19 years reached $\$ 4.4$ billion. During the years of economic cooperation more than 70 joint ventures were created. ${ }^{63}$ In 2012, at the end of the Fourth Meeting of Ministers of Foreign Affairs of the "Central Asia plus Japan Dialogue", a joint declaration on the construction of a new partnership between Japan and Central Asia was signed. The representatives of the participating countries declared their intention to raise the partnership between the two countries to a higher level and to diversify their cooperation. The following five major tasks were identified within the framework of that declaration, which requires joint resolution and actions: improvement of the trade and investment climate, environmental issues, introduction and development of energy conservation and alternative energy

\footnotetext{
${ }^{61}$ Hisane Masaki, Japan's New Energy Strategy, AsIA TimEs (January 13, 2006). Available at http://www.atimes.com/atimes/Japan/HA13Dh01.html (last visited January 27, 2015).

${ }^{62}$ KazAKhSTANSKaya Pravda (April 12, 2007).

${ }^{63}$ Yaponiya za 19 let investirovala v Kazakhstan $\$ 4.4$ milliardov (in Russian). For 19 Years Japan Has Invested to Kazakhstan \$4.4 Billion, KAPITAL (Feb. 18, 2013). Available at http://kapital.kz/economic/11312/yaponiya-za-19-let-investirovala-v-kazahstan-4-4-mlrd.html (last visited January 28, 2015).
} 
sources to achieve the Millennium Development Goals (MDGs), stabilization of the situation in Afghanistan, and cooperation on disasters. ${ }^{64}$ This statement opens new areas of cooperation between the two countries. During the visit of the Minister of Economy, Trade and Industry of Japan, Yukio Edano in 2012, the parties signed six memorandums related to the development of economic cooperation between the two countries, including in the field of innovation, where the increase of the volume of the Japanese investments in the form of new and innovative technologies is very important to Kazakhstan. ${ }^{65}$

The Kazakhstan-Japan relations have a great potential for realization in a variety of other directions, especially in the development of green economy. The most promising area of cooperation from the scientific and technological point of view is the resource economy. Such cooperation is particularly important given the fact that Japan is ahead of Kazakhstan by almost 20 times in terms of energy efficiency. The first results of the countries' cooperation in the energy sector could be seen from the practical application of the energy-saving technologies and modernization of the coal-fired power plants by Asuka Green Investment and Mitsubishi Research Institute, Inc. For instance, as a result of such modernization at the Almaty thermal power plant-2, $\mathrm{CO} 2$ emissions were reduced by 820 tons per year and efficiency of the plant was increased by $19 \% .{ }^{66}$ In the near future, the Japanese experts are planning to expand cooperation with other power utilities in the field of the advanced energy saving technologies. Nine bilateral documents were signed during the Fourth Meeting of the Joint Commission of Japan, Kazakhstan, and the Private Sector on Economic Cooperation on February 18-20, 2013 in Tokyo, including the following memorandums of understanding signed by the National Nuclear Center of the Republic of Kazakhstan:

Memorandum of understanding with the Japan Atomic Energy Agency (JAEA) for cooperation in research and development of the future of nuclear power and creation of new industries (creation of safe high-temperature gascooled reactors, research and development of radioisotope products for

\footnotetext{
${ }^{64}$ Zhanai Omarov, Na puti sotrudnichestva i sozidaniya (in Russian). On the Path of Cooperation and Creativity, KAZAKhSTANSKAYA PRAVDA (Aug. 3, 2013). Available at

http://www.kazpravda.kz/news/view/na-puti-sotrudnichestva-i-sozidaniya (last visited January 28 , 2015).

${ }^{65}$ Ibid.

${ }^{66}$ Kazakhstan i Yaponiya razvivayut sotrudnichestvo v energeticheskom sektore (in Russian). Kazakhstan and Japan Develop the Cooperation in the Energy Sector, ZAKON. KZ (June 27, 2013). Available at $\mathrm{http}: / / \mathrm{www} . z a k o n . k z / 4564313-k a z a k h s t a n-i-j a p o n i j a-r a z v i v a j u t . h t m l$ (last visited January 28, 2015).
} 
research reactors and medical purposes, research of heavy accidents for light water reactors, etc.) and

Memorandum of Understanding on cooperation with the Japan Atomic Power Company (JAPC) and Marubeni Corporation (MUS, Ltd.) providing for strategic planning and addressing the long-term development of nuclear energy in Kazakhstan (joint participation in the development of feasibility studies, construction and launching of the nuclear power plants, training of the personnel for nuclear industry and other issues). ${ }^{67}$

For Kazakhstan, the benefits of its cooperation with Japan include the increased levels of FDI and greater access to new technologies and markets. This in its turn would enable Kazakhstan to transit over towards a more high-value production. The results of such new form of cooperation have already started to show. For instance, from 2010-2013 positive changes in the economy of Kazakhstan could be seen for most part due to the implementation of the Industrial and Innovation Development Program that was discussed earlier in this section. The priority investors were attracted to a number of leading projects implemented as part of that program. For example, in cooperation with Toshiba Corporation and Sumitomo, a project on the production of pure and rare metals for the nuclear industry was launched in the East Kazakhstan region. Similarly, a project on the assembly of motor vehicles in Kazakhstan was launched in cooperation with Toyota Motors Corporation. As a result of these and similar joint projects within the framework of the Industrial and Innovation Development Program 13,000 new permanent jobs were created in Kazakhstan. In addition, exports of manufactured goods in 2012 increased by $29 \%$ to $\$ 4.2$ billion in comparison to the 2011 numbers and by $14 \%$ in comparison to the 2008 numbers, the year in which the exports of manufactured goods were top high since 1991. Finished products are now shipped to 111 outside markets. ${ }^{68}$

Kazakhstan's uranium production in 2006 ranked third in the world. After Koizumi's visit in 2006 and the inflow of the Japanese investments in the Kazakhstan's uranium industry following that visit, the uranium production levels in Kazakhstan started to grow every year, and by 2009

\footnotetext{
${ }^{67}$ National Nuclear Center of the Republic of Kazakhstan, Yaponiya i Kazakhstan - sotrudnichestvo $v$ sfere atomnoi energetiki i innovatsionnykh tehnologii (in Russian). Japan and KazakhstanCooperation in the Field of Nuclear Energy and Technology Innovation. Available at http://nnc.kz/Novosti/Atomnaya-energetika/collaboration-japan-kazakhstan.html (last visited January $28,2015)$.

${ }^{68}$ Meirambek Baigarin, $V$ Kazakhstane $v$ ramkah realizatsii gosudarstvennoi programmi forsirovannogo industrial'no-innovatsionnogo razvitiya $v 2013$ godu budet sozdano 13 tisyach novyh postoyannih rabochih mest (in Russian). In 2013, within the Framework of the State Program of Industrial-Innovative Development Will Be Created 13,000 New Permanent Jobs, KAZINFORM (May 6, 2013). Available at http://www.inform.kz/rus/article/2556099 (last visited January 28, 2015).
} 
Kazakhstan became the world's leading producer of uranium with the $28 \%$ share of the world's uranium production ranking ahead of Canada with its $24 \%$ share and Australia with its $19 \%$ share. ${ }^{69}$ The Japan-Kazakhstan minerals-based strategic cooperation exhibited signs of being mutually beneficial for both countries.

However, as a result of the March 11, 2011 earthquake and tsunami in Japan, a series of major accidents followed at the Fukushima-1, 2, 3, and 4 nuclear power plants. The Fukushima accidents forced the Japanese Government to abandon its plans for the development of peaceful nuclear energy for the time being.

However, the abandonment of the nuclear power development plans did not affect the strategic cooperation with Kazakhstan. On the contrary, the cooperation of the countries became more diversified by virtue of being extended into other areas, such as transport logistics, biotechnology, and space exploration. For example, Kazakhstan and Japan have strengthened their cooperation in the field of transport logistics by signing on August 31, 2012 a memorandum of cooperation between Kazakhstan national company Kazakhstan Temir Zholi ${ }^{70}$ and SENKO CO., Ltd. of Japan. ${ }^{71}$ This project is of great strategic importance for the two countries in terms of increasing traffic from Japan to Europe through Kazakhstan. The creation of the joint integrated transport and logistics products for all transit routes through Kazakhstan will enable the two countries to become competitive partners given the unstable political as well as economic conditions in the world. As to the other new fields of cooperation, a Kazakhstani company, KSP Steel entered into an agreement with the Japanese partners on the joint development of the Kazakhstani oil and gas industry and support from the Japanese partners in connection with the Kazakhstani efforts to increase its exports of steel products; a Kazakhstani company Dala Mining entered into a joint development project with Itochu Corporation for mining and processing of the tungsten-molybdenum ore deposits in Koktenkol, Kazakhstan; the Kaznex Invest agency signed a memorandum with Chiyoda Consulting Co., Ltd. for the support of the production of the molybdenum powders and plates of 120 tons per year and a memorandum with Sumitomo Corporation on energy projects. In addition, the aviation equipment, communication systems, and optical electronic devices are to be produced in

\footnotetext{
${ }^{69}$ KAZAKHSTANSKAYA PRAVDA (April 12, 2007).

${ }^{70}$ Temir Zhol means railroad in Kazakh language.

${ }^{71}$ Kazakhstan i Yaponiya ukreplyayut sotrudnichestvo v oblasti transportnoi logistiki (in Russian). Kazakhstan and Japan Strengthen the Cooperation in the Field of Transport Logistics, KAZINFORM (August 31, 2012). Available at http://www.inform.kz/rus/article/2490940 (last visited January 28, 2015).
} 
Kazakhstan within the frameworks of joint projects with the Japanese companies. $^{72}$ The Kazakhstan-Japan cooperation is extending now into the areas of defense and space cooperation.

\section{CONCLUSION}

Twenty years have passed since Kazakhstan and Japan established their diplomatic relations. During this time, the two countries continuously tried to find mutually beneficial entry points in their bilateral relations. Initially, the relationship between Japan and Kazakhstan was limited primarily to the provision by Japan of the ODA grants to Kazakhstan. Kazakhstan, however, was in need for foreign investments for the development of its industries. In 2002-2006, the governments of both countries tried to increase their economic interaction by attracting investments in the oil and gas industry of Kazakhstan. However, those efforts did not bear significant results. The levels of the Japanese foreign investments in Kazakhstan during that time were low, as the Japanese businesses did not feel that the low rate of return in light of various factors, including the preemptively strong position of the Russian and Chinese enterprises in Kazakhstan, was worth the risk. The turning point in the development of the relations between the two countries could be seen at the time the companies refocused on the minerals-based cooperation (specifically, cooperation in the field of nuclear energy and rare earth metals production). The cooperation has helped to transform Kazakhstan from an ODA-recipient to an equal partner. Japan and Kazakhstan have found an ideal point of cooperation, whereby Japan can supply its high technologies that Kazakhstan needs to transition from being simply a raw materials supplier to a producer of processed raw materials, and Kazakhstan, rich in uranium and rare metals, the materials that Japan needs for internal consumption, can supply the requisite levels of these materials to Japan. Kazakhstan now needs to take advantage of its position and transform into a producer of the higher-value goods. Even the March 2011 Fukushima accident at the nuclear power plants did not hinder the development of cooperation between the two countries; on the contrary, it resulted in the diversification of their relations. Again, it shows that the Kazakhstan-Japan relations are based on as strong partnership, which can overcome problems and deepen the cooperation in the mutually beneficial

\footnotetext{
${ }^{72}$ Yaponskie kompanii namereny investirovat'v ryad proektov v Kazakhstane (in Russian). Japanese Companies Are Going to Invest in a Number of Projects in Kazakhstan, OILNEWs (February 19, 2013). Available at http://oilnews.kz/1/novosti/novosti-tek-kazaxstana/yaponskie-kompanii-namerenyinvestirovat-v-ryad-proektov-v-kazaxstane/ (last visited January 28, 2015).
} 


\section{STRATEGIC COOPERATION BETWEEN JAPAN 387}

fields. This cooperation is a good example of the success of the Japan's foreign policy in Central Asia. 